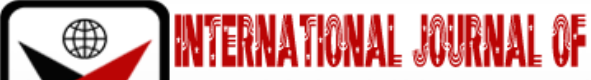

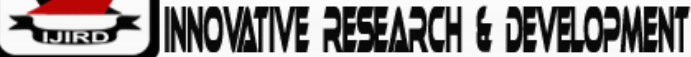

ISSN 2278-0211 (Online)

\section{Parental Contribution to Their Children's Education in Public Secondary Schools in Lushoto District Council, Tanzania}

Herieth Elifuraha Kagosi
Master Candidate, Department of Educational Psychology, Evaluation Assessment and
Curriculum, Mwenge Catholic University, Moshi Tanzania
Dr. Timothy Mandila
Lecturer, Department of Educational Psychology, Evaluation Assessment and Curriculum,
Mwenge Catholic University Moshi, Tanzania
Dr. Gadi Koda
Senior Lecturer, Department of Educational Psychology, Evaluation Assessment and
Curriculum, Mwenge Catholic University, Moshi, Tanzania

\begin{abstract}
:
The study investigated parental contribution to their children's education in public secondary schools in Lushoto District. The study was guided by two (2) research questions. The study was guided by Epstein's theory of school family and community partnerships. In this study, the researcher adopted a mixed method approach under which a concurrent embedded design was used. The targeted population were 53 public secondary schools which involved 53 heads of schools, 2160 students, 2160 parents and 486 teachers as well as 1 DSEO making a total population of 4860 respondents found in Lushoto District. The study used probability sampling and non-probability sampling techniques. The sample size comprised 6 public secondary schools, 6 heads of schools, 96 teachers, 90 parents, 1 DSEO and 300 students which makes a total of 493 respondents. Information required to answer the research questions in this study was collected using questionnaires and in-depth interview guides. The study found that parents are not assisting their children with homework assignments. It has been found that majority of parents are not regularly attend school meetings to follow-ups their children education. Based on the findings it was concluded that parents have to lend support by taking an interest in the homework that their children bring home and finding the most effective ways to help them with assignments. Parents with their children at schools has to attend school meeting to know the educational progress of their children and to engage themselves to determine their level of understanding. The study recommended that government under the Ministry of Education Science and Technology (MOEST) should make sure that the parents are involved effectively to their children education by assisting their children with homework and heads of schools should encourage parent to attend school meeting to be aware with their children education.
\end{abstract}

Keywords: Parental involvement, Students' education, Guidance and counselling, Parent's assistance

\section{Introduction}

Education is essential for the development of society. The more educated the people of a society are, the more civilized and well-disciplined the society might be. Mainly, family has responsibility to socialize children for making them productive members of society. The children's first school on earth is the parents. It is from the parents that they learn various life practices such as language, greeting and other forms of socialisation. Children have two main educators in their lives: their parents and their teachers at school (Kibaara\&Ndiragu, 2014). In deed there is no clear-cut demarcation between where the roles of parents start and end and where the teachers' role starts and ends in educating the child. Parents being so important it has been realised that the nature of their participation in their children's education determines their academic success. When schools and families work together children have higher achievement in school and stay in school longer (Abbasianet al, 2020).

The more the parents involve in the process of imparting education to their children, the more the children might excel in their academic career and to become the productive and responsible members of society. It has been assumed that academic achievement of students may not only depend on the quality of schools and the teachers, rather the extent of parental involvement has vital role to play in academic achievement of their kids (Rafiq et al, 2013). The study conducted by Mukethe (2015)in Kenya indicated that most of the parents were not involved towards curriculum implementation at all especially in provision of teaching and learning facilities in the school these implies that their contributions were not considered in shaping the education of their children.

Parental contribution in the education of their children, like many other forms of community partnerships such as the Parent Teacher Association (PTA) or Parent Teacher Organization (PTO), assist their children with homework 
assignment and paying of all school contribution might help to improve students' academic success. Limited or lack of parental contribution to the education of their children has been considered part of the shortcomings of the children's education (McLean et al, 2017). Various aspects of parental contributions to their children education such as participation, partnerships and a variety form of interactions have differential effects on students' academic outcomes. The academic achievement of students in school depends much on how parents commit themselves in participation of educational matters regardless their environment and status (Amuda\& Ali, 2016).

Most parents' desire was to spend quality time with their own children at home during the evenings and weekends rather than attend meetings at the school. Kilgoet al, (2018) pointed out that parent in their daily commitments and responsibilities made it extremely difficult for them to cope with activities such as homework supervision or attend school meetings. Some parents may feel that they are not able to help their children with school work due to lack of preparation and knowledge. It should be noted that there is a widely held view that Parents are essential in their children's education through their participation in their children's educational activities like helping in doing homework, attending PTA meetings, providing a conducive environment at home amongst others (Baeck, 2010). This is because the outcomes of parents engaging in the educational activities of their children improve the children's academic performance as well as their behavior (Powell et al, 2010). When parents actively participate in academic matters by contacting with schools to share information about their children development, students are greatly benefited in aspects such as intellectual stimulation, positive learners' attitudes towards school matters and better students' school attendance (Maxwell \& Yemini, 2019).

Evidence from the study of Abuyaet al, (2014) revealed that girls who enjoyed parental involvement in their schooling significantly improved their educational aspirations. Hence, there is evidence that parental participation in their children's schooling goes a long way in shaping and moulding their children's educational outcome. Even though the role of a parent in their children's education evolves as children gets older, it's important to remember that parents remain role models. Their attitudes towards education can both inspire children and empower them as they go through their own educational journey. The Global Partnership for Education believes that parents should be actively involved in their children's education, and be part of efforts of ensuring that all children receive a quality education (Ntekane, 2018).

Masaboet al, (2017) from Kenya argues that students' academic performance has been affected by parents behavior of not attending school and class sessions which caused by the poor follow up made by teachers and parents to the children. Moreover, majority of parents were found not to attend at school meeting whenever they are called by school administrators, this might reflect most of parents are they did value the education of their children. Teklemariam (2010) have found that teachers are sometimes reluctant to encourage parents' involvement in their children education activities because they are uncertain about how to involve parents and still maintain their role as "experts". They are uncertain about how to balance their concern for the group of children against more personalized concern for each individual child, which they believe would be expected if parents were more involved. Sometimes parents lack time to involve themselves in school program because they have their own program at home.

According to Gonida\& Cortina, (2014) current research shows that the involvement of family in learning helps to improve student performance reduces absenteeism and restores parent's confidence in their children's education. Learners with parents or caregivers, who are involved in learners' education, earn higher grades, they have better social skills and show improved behaviour. This is something that we as a community and the world at large are in need of, as it would highly contribute in reducing crime and poverty. In addition, Bill, (2016) proves that it is an obligation to ensure that all children without discrimination in any form have access to the service of education. This also indicates that parents accept a particular responsibility for the well-being of their children, including their care, protection, safety, and growth in their education (Spies \&Heystek, 2015).

In Tanzania the participation of parents in their children's learning is articulated in the education act No. 25 of 1978-section 38 (URT, 1978), where parents are equipped with the power to participate in the decision making of the school affairs. Furthermore, in the education circulars of 2015 and 2016 (URT, 2015, URT, 2016) it is stipulated that parents should participate in their children's learning through buying teaching and learning resources. However, so far, the parents' participation in their children's learning in Tanzanian secondary schools has not reached the maximal level as revealed by studies. Kapinga (2014) found out that parents' level of education which influenced the rate of parents' participation in students' learning is still very low. Uwezo (2013) found out that one out of four parents help children with homework, and one out of four had discussed about education at a school committee meeting while four out of ten had spoken with their children's teachers at least once.

In spite of the fact that there are great benefits of parental involvement on students' academic performance, in Tanzania, parental involvement in community secondary schools has been limited, that some parents have not been involving themselves in educational matters (Nghambi, 2014). Mauka (2015) asserts that, there is poor communication between parents and school administration; there is negligence of school matters among parents in community secondary schools. Among the factors that influence the poor academic performance in secondary schools is lack of parental involvement (Makaye, 2014). However, the poor academic performance in community secondary schools is largely influenced by lack of parental involvement in education matters (Wilson, 2013). Thus, when parents do not play their role effectively, it is certain that poor academic performance among students in community schools will be accelerated. This has grounds to Abuyaet al, (2014) assertion who posits that, students who receive educational support from their parent perform well in their education while those who do not receive parental support perform poorly in their education.

Dookie (2013) found out that students with involved parents, no matter what their income or background is, were more likely to earn higher grades and test scores, and enroll in higher-level programs; be promoted, pass their classes, and earn credits; attend school regularly, have better social skills, show improved behavior, and adapt well to school and 
graduate and go on to postsecondary education. Furthermore, despite the fact that, parental involvement is generally a salient contributor to student academic achievement in secondary schools, it appears to be on a decline locally despite being associated with positive outcomes for students especially in public ward secondary schools(Joseph, 2014). This means parental participation in children education differs from school to school, from community to community and from parent to parent thus making it difficult to achieve the proven benefits of effective home-school relations in all schools. In this view, this study investigated the parental contribution on their children's education in public secondary schools in Lushoto District Council.

\section{Statement of the Problem}

The parental contributions in education matters play a great role in enhancing students' academic performance (Makaye, 2014). The effective participation of parents in education arena both at home and at school is characterized by respect and mutual relationship between parents and teachers. In Tanzania the participation of parents in their children's learning is articulated in the education act of 1978 (URT, 1978), where parents are provided with the power to participate in the decision making of the school affairs. Moreover, in the education circulars of 2015 and 2016 (URT, 2015, URT, 2016) it is stipulated that parents should participate in their children's learning through buying teaching and learning resources. However, so far, the parents' participation in their children's learning in Tanzanian secondary schools has not reached the maximal level as revealed by Kapinga (2014) who found out that parents' level of education which influenced the rate of parents' participation in students' learning, is still very low. Uwezo (2013) found out that one out of four parents help children with homework, and one out of four had discussed about education at a school committee meeting while four out of ten had spoken with their children's teachers at least once. Additionally, Masaboet al, (2017) reveal that parents do not participate fully in their children's learning especially on contributing food for their children. Therefore, these studies indicate that most parents in Tanzania are not fully involved in their children's learning process in secondary schools. Due to such circumstances this study aimed to explore the extent to which parents contribute in their children's education through various school activities either at school or at home so as to enhance learning in public secondary schools. Therefore, this study investigated the parental contribution on their children's education in public secondary schools in Lushoto District Council.

\section{Research Questions}

This study was guided by the following research questions.

- To what extent does parents' assistance with homework's enhance their children education in public secondary schools in Lushoto District?

- To what extent does parents' attend school meetings enhance their children education in public secondary schools in Lushoto district council?

\section{Significance of the Study}

The findings of this study bring knowledge to the field of curriculum and institution on the contribution of parents into their children's academic activities. This knowledge helps curriculum developers to encourage parents to help their children through assisting them with homework when they are at homes. The knowledge also helps parents to identify the importance of assisting their children with homework assignments which may improve their children in academic achievement. The study provides awareness to the students on how to interact with their parents through academic issues like to do together the homework assignments with their parents. This study also provides knowledge to the policy makers in the field of education to formulate policy that encourages parents to attend school meeting which enhance their children academic success. The findings from the study provide information to the parents about the importance attending school meeting to know the education development of their students.

\section{Theoretical Framework}

This study was guided by overlapping spheres of influence theory which was developed by Joyce L. Epstein in 1987. Overlapping spheres of influence theory is an influential theory used to examine and define the relationship between schools, families, and communities. The student is located at the center of these three spheres, since she or he is the most important contributor to his or her academic success. The spheres help influence and guide the student's success. Epstein's theory emphasizes the need for reciprocal relationships of parents, educators and community partners to identify common goals for students' academic success and to appreciate each other's contribution to student development (Conrad \& Serlin, 2006). In Epstein's view, the most beneficial dynamic in the collaborative partnership of child development, particularly in the education of children, is that primary actors; parents and teachers, understand the roles that each play. She stated that through their interactions, parents, educators, and community partners establish social ties and exchange information that accumulates to improve children's school and learning experiences (Conrad \& Serlin, 2006).

The strength of the theory is that, it emphasizes the school's administration provide information of the students to parents who want it or who need it, not just to the few who can attend meetings at the school. The theory believes that all stakeholders in a child's education have mutual interests and influences. The primary shared interest is a caring concern that the child be successful. Additionally, the theory suggests that stakeholders' shared interests and influences can be promoted by the policies, actions, beliefs, attitudes, and values of the stakeholders. Also, overlapping spheres of influence theory believes that schools and families share similar characteristics. 
The weakness of the theory is that, it focuses only on the parental involvement in shaping students' behaviours. But Epstein did not suggest what measures to be undertaken to combat challenges occur during parental contribution on their children education. The theory also did not portray out the techniques that can be used to enhance parental contribution in school activities.

This theory is applicable in education institutions where it allows the parents and teachers work together in maintaining and improve children education and behaviours. Overlapping spheres of influence theory shows how cooperative work produces positive outcomes. Theory has practical applicability in guiding how the parents should play their roles in guiding the students learning to realize positive outcomes in education.

\section{Empirical Review}

\subsection{Parent's Assistance on Homework's in Enhancing Children Education}

Li \& Hamlin, (2019) did a study about is Daily Parental Help with Homework Helpful? The study used crosssectional survey design with mailed questionnaire for teachers and principals. The study involved 73 teachers 4 teacher educators and 4 principals. Results indicated that low prior achievement, socioeconomic disadvantage, and minority status were associated with a high propensity to provide daily homework help. Daily parental homework help was also associated with improved achievement for children whose parents had a high propensity to provide daily homework help. These patterns suggest that complex factors induce daily parental homework help and that these factors are related to heterogeneity in the relationship between daily parental homework help and achievement.The sample size for the teacher educators and the principals was a little bit small to make the findings of the study to be generalized to the target population. This reflects inadequate empirical knowledge in parental relations that needs to be established.

Sapta et al, (2018) conducted a study about assistance of parents in the learning at home at Kisaran. The study used a survey design with a questionnaire as the sole instrument to collect data from the parents, head teachers and community leaders. The study involved 10 schools, 24 parents, 10 community leaders and 10 principals. The schools were sampled using stratified random sampling; the parents were selected using simple random sampling while the principals and the community leaders were selected using purposive sampling. From the results of the study note that parental assistance at home studying in the city of Kisaran is very low. This is known from the results of a survey that states that the concern of parents to their children's homework is rarely categorized. In general, parents entrust their children's learning after school hours to tutoring and private tutors. The sampling technique used to select the community leaders and the head teachers who participated in the study was not congruent with the design used for the study.

Dettmers et al, (2019) conducted a study about antecedents and outcomes of parental homework involvement: how do family-school partnerships affect parental homework involvement and student outcomes? The study used descriptive survey design with a questionnaire for the teachers and parents. The questionnaire for parents had only six items all of which were open ended question items. The study was conducted in ten (10) secondary schools selected nonrandomly and it involved 12 teachers and 15 parents selected purposively.The structural equation model revealed a positive relation between EFSC and the quality of parental homework involvement, which in turn was positively associated with school performance and well-being. Moreover, we found that the quality of parental homework involvement mediated the relations of EFSC with achievement and well-being. The results of our study highlight the role of EFSC as a key performance factor that helps to improve the quality of parental homework involvement, thereby promoting student achievement and well-being. The design did not match with the sampling techniques used; the study adopted a survey design but employed non-probability sampling procedures instead of using probability sampling procedures. The questionnaire for the parents did not adequately sample all the items that answered the research questions and yet the parents were major players in the study. The study did not solicit information from the heads of secondary schools in the area of study and yet these are the people who are supposed to work closely with the parents to ensure they are actively involved in student's education.

Paul \&Ngirande (2014) conducted a study on the impact of parental involvement on student performance: A Case Study of a South African Secondary School. The study used a quantitative research approach. Data was gathered using a questionnaire administered to 114 students' parents. The main findings are that all the parents who responded are highly involved with their children's education. They have high expectations towards their children's education and performance. Three parental involvements constructs, that is, parenting, parent-teacher communication and home and family support were found to be positively related to performance. Results further indicate that home and family support is the most significant factor that determines a learner's performance. The study showed that family support encourages students to perform better in their exams and enhance good students' academic achievement. Moreover, children's homework is considered to be important by each parent and they all assist their children with homework. However, the researcher did not explain clearly what education level the parents have to help their children with their homework. Therefore, the current study will investigate the extent parents contribute to their children's education.

Mahuro \& Hungi (2016) did a study on the parental participation improves student academic achievement: A case of Iganga and Mayuge districts in Uganda. This study adopted a cross-sectional design to collect quantitative data. The targeted participants of this study were heads of schools, teachers, students and parents. The study found out that home becomes the first school that all students attend as parents actively engage with children during their development cycle. These may include: assisting parents to understand some activities in the school curriculum which their children require during their schooling progression, devise a mechanism that informs parents on how to monitor their children's practices and behaviour, educate parents on how to train their children on how to set and achieve appropriate career goals and how to choose school programmes that best fit the student's schooling interest. 
The study showed that parents helping their children with education related issues like teaching their children and helping doing home works and assignment improve students' academic achievements. Students who enjoy such parental involvement have improved test scores, improved homework completion and they develop a positive attitude towards schoolwork. However, the study did not include parents' level of assistance when helping their children with education related issues like home works and assignment. In this regard, there is a need to consider parents level of assistance before helping them to teach their students. Therefore, the current study will investigate parental contribution to their children education.

Nzilano \& Mtoro (2017) conducted a study on the influence of parents on students' academic performance in Tanzania: The case of Ilala Public Schools. The study used quantitative and qualitative approaches with a cross-sectional survey design. The study targeted heads of schools, teachers, parents and students. Data were collected through interviews, questionnaire and documents reviews. The findings show that parents were not involved in various school activities because of their low awareness among themselves, daily activities and being ignored by school administration. The showed that majority of parents were having low awareness about the involvement in their children education. However, the researcher did not explain how parental contribution had an impact to children education. Hence, this study was conducted to investigate the parental contribution to their children education.

\subsection{The Involvement of Parents in School Meetings on Children Education}

A qualitative study conducted by Porumbu \& Necşoi (2013) on relationship between parental involvement and children's school achievements in Romania. The study targeted parents, students and teachers. The study used interview guide, observation guide and focus group discussion as data collection instruments. The findings showed that several variables that are consistently associated with high levels of academic achievement: an authoritative parenting style, parental high and clear expectations and aspirations for their children's school results, communication between parents and children about their school activities and plans for the future, parents' communication with teachers regarding their child's progress or difficulties.

Another study done by Shute, Hansen, Underwood, Razzouk, (2017) on the review of the relationship between parental involvement and secondary school students' academic achievement. The study involved 40 teachers chosen at random from five different schools and 20 parents selected randomly from five schools. The study used descriptive survey design with a questionnaire for the teachers and the interview guide was administered to the parents. The study found several variables with correlations to academic achievement show promise: communication between children and parents about school activities and plans, parents holding high expectations/aspirations for their children's schooling, and parents employing an authoritative parenting style.

\section{Methodology}

The study adopted a mixed method approach under which a concurrent embedded design was used. The study pursued the quantitative approach through administering questionnaires to students and teachers while qualitative approach through interviewing heads of schools, parents and DEO. The target population was 53public secondary schools, 53 heads of schools, (2160) students, (486) teachers, 2160 parents and 1 district education officers. Therefore, the sample size of this study was 493 participants out of 4860 where stratified and simple random sampling techniques were applied to get 96 teachers and 200 students while 1 DEO and 6 heads of schools were directly included due to their virtual administrative roles as the leader/supervisor of the whole school activities. The snowball sampling technique was employed to get 90parents so as to participate in the study. Data from questionnaires were analyzed in terms of frequencies, percentages and presented in tables where applicable. This was achieved with the aid of computer software "Statistical Package for Social Sciences" (SPSS) version 22. The qualitative data from interview guide were analyzed by using narration then merging the results.

\section{Findings and Discussion}

This study sought to find out the parents' contribution to their children education performance in public secondary schools in Lushoto district council. The study investigates the extent that parents' assistance with the homework enhance their children education performance in public secondary schools and the extent of parents attend school meeting enhance their children education in public secondary schools.

\subsection{Parent's Assistance on Homework's in Enhancing Children Education}

The study sought to find out the extent to which parents' assistance with homework's enhance their children education in public secondary schools. Information to address this question was acquired from students, parents and teachers. Questionnaire was used to collect information from students and teachers while interview guide for parents. Based on students responds, it is clear that the parent does not assist their children in doing homework with a percentage of 73.5. This is because they are too busy and not understanding the subject matter or pushback from their kids. Homework is an opportunity for children to learn and for families to be involved in their children's education. However, helping children with homework isn't always easy. During an interview with parents about how they assist their children with home works, one of the parents said;

I didn't provide any assistance to my children with their home works. This is because, when I arrive at home it is too late and my children are already sleep. Then, it is difficult for me to assist them with their homework. (24th May 2021)

Another parent said; 
I have low education level of standard seven but I do follow my children education by checking their exercise books every weekend if they are at school the whole week. However, I do not assist my children with their homework since I don't have the knowledge pertaining the subject matter.(25th May 2021)

This means that most of the parents do not assist their children with the homework due to their low level of education that they cannot be able to understand what their children are studying. Hence, there is less parental contribution in helping the children home works. Helping with homework is an important responsibility as a parent directly supports the learning process. Parents' experience and expertise is priceless. One of the best predictors of success in school is learning at home and being involved in children's education. Parental involvement with homework helps develop self-confidence and motivation in the classroom. This is accordingly with Nzilano\&Mtoro (2017) who suggested that parents are not involving in various school activities because of their low awareness among them, daily activities and being ignored by school administration. Parents were having low awareness about the involvement in their children education due to low level of education.

About $73 \%$ of students reported that parents encourage them to take control of the learning process of their homework. This implies that parents are involved at home by guiding their children to manage homework and other commitments and engaging in discussions about values and attitudes regarding education as parents can make a difference through warm encouragement and a positive outlook and by communicating high expectations to children. This study as well expose further that slightly more than half (53\%) of the students agreed that parents let them figure out answers on their own while offering helpful hints and positive feedback as needed. Thus, the helping process with homework parents should avoid trying to control the process and should also resist the temptation to complete assignments for their children. Instead, they should let their children figure out answers on their own while offering helpful hints and positive feedback as needed. It seems that parents who are interested in education can find out for themselves how the child is progressing with studies and thereafter encouraging him/her to spend reasonable amount of time studying when they are at home. During an interview with the heads of schools about how they encourage parents to assist their children with homework at home. One of the head of school said that:

During school meeting, I usually encourage parents to help their children with some homework since it's the

best way to understand their children if they attend school and attend all class session.(24th May 2021)

This implies that heads of schools use school meetings to encourage parents to assist their children with homework. These findings are corresponding with that conducted by Paul \&Ngirande (2014) who revealed that parents are highly involved with their children's education. They have high expectations towards their children's education and performance. Three parental involvements constructs that are, parenting, parent-teacher communication and home and family support were found to be positively related to performance According to Paul \&Ngirande (2014) reveals that home and family support is the most significant factor that determines a learner's performance as family support encourages students to perform better in their exams and enhance good students' academic achievement, hence children's homework should be considered to be important by each parent and assist their children's homework.

Also; the findings reveal that $64.5 \%$ of students disagreed that parents reduce home activities to allow enough time for my studying. This indicates that they are not allowing enough time for their children studies as they do not reduce home activities to allow enough time for their children studying. On the other hand, greater more than half (64\%) of students agreed that parents provide really examples that makes them easily understand the subject concept. This implies that most of the parents provide life situations examples to their children when doing homework that makes easy for understanding the subject matter.

Also, majority $83 \%$ of students reported that parents praise and encourage them for the better answers. This suggests that parents praise and encourage their children for the better answers when doing homework as praise and encourage nurture children confidence and sense of self. By using praise and encouragement, parents are showing their child how to think and talk positively about themselves. They are helping children to learn how to recognize when they do well and feel proud of themselves. During an interview with District Education Officer (DEO) on how parents assist their children as their responsibilities to their children. DEO pointed out that:

Parental involvement includes a wide variety of actions parents take for the benefit of children's academic success at school and usually it starts at their home. These include parenting style, parental expectations and aspirations, home rules and parental supervision; parents' attitudes towards children's activities, helping with homework, visiting the school to talk to teachers, and beliefs regarding their child's education.(28 ${ }^{\text {th }}$

May 2021)

This means that parental involvement in the education of students begins at home with the parents providing a safe and healthy environment, appropriate learning experiences, support, and a positive attitude about school. The study found out that parents helping their children with homework, these activities produce a school-oriented family and encourage parents to interact with the school curriculum. These findings are in line with Glynn, (2016) who hold that activities to encourage learning at home provide parents with information on what children are doing in the classroom and how to help them with homework which includes information for families on skills required for students in all subjects at each grade, information on homework policies and how to monitor and discuss schoolwork at home, as well as family participation in setting student goals.

The result revealed that $81.5 \%$ of students disagreed that parents create positive study environment by allocating family time for doing homework. This implies that parents do not create positive study habits by allocating family time for doing homework. And hence they are not carving out time for their children to do homework while engage in a study activity such as reading, rather than watching television and relaxing. Also, greater majority (97\%) of the students 
disagreed that parents provide them with a teacher at home for remedial teaching classes. This means that parents do not provide their children with a teacher at home for remedial teaching classes as most of them are not good financially.

Furthermore, the data revealed that parents set up a homework-friendly area to conduct homework as reported by $65 \%$ of the students while $28 \%$ disagreed. This implies the slightly less than two thirds of students said that their parents set up a homework-friendly area to conduct homework. On the other hand, slightly more than two thirds (68\%) of the students agreed that parents keep distractions to minimum to allow them to do homework effectively while $23 \%$ disagreed. This indicates that parents keep on distractions to a minimum as some children prefer to do homework straight after school, whereas others have after school commitments or prefer to 'unwind' first so parent should establish a suitable time and place for completing homework, ideally somewhere with no interruptions and when distractions are at a minimum. Encourage them to they stick to this routine, as making study a consistent part of their daily lives is a great way to develop healthy homework habits. These was supported by Li \&Qiu (2018) who argued that parenting behaviour and educational support for their children could cultivate children's learning habits and affect academic performance. Also, Mahuro\&Hungi (2016) reported that parents helping their children with education related issues like teaching their children and helping doing homework and assignment improve students' academic achievements. Students who get parental involvement have great improvements on test scores, improved homework completion and they develop a positive attitude towards schoolwork.

\subsection{The Involvement of Parents in School Meetings on Children Education}

The study sought to find out the involvement of parents in school meetings on children education in public secondary schools. The researcher gets information to address this research question from students, teachers and heads of schools as well as parents. Questionnaire was used to collect information from students and teachers. Interview guide was used to get information from parents and heads of schools.

With respect to students' response; the findings show that about $54 \%$ of students disagreed that parents meet face to face with head of school to discuss about students matters while 33\% agreed. It was investigated that few parents meet face to face with head of school to discuss about students matters, signifying low participation in decision making and school management. More than half (59\%) of the students disagreed that parents meet face to face with class teachers to discuss about their children academic progress while 30\% students agreed. This suggests that few parents meet with the teachers to look and discuss about their children academic progress while others parents do not meet individually with the teachers to look and discuss about their children academic progress.

The data also portray that parents participate on school fund raising meeting to enhance their children education was disagreed by 78\% of students. This indicates that more than three quarters of parents do not participate in on school fund raising meetings when schools had voluntary fundraising events most of the parents do not participate. Parents frequently discuss about their children education on open day was disagreed by slightly more than half (58\%) of students. About three quarters (75\%) of the students disagreed that parents participate in parent's teachers' association activities. This suggests that parents do not participate in parent's teachers' association activities in order to discuss about school progress, pass rates, discipline, and academic success whereby parents will have a sense of ownership in this school.

Also, the data depict that $79 \%$ of students agreed that parents attending school after being called several times by school administration. On the other hand, a greater majority (90\%) of students agreed that parents attend school meetings only once per year to make follow ups of their children academic progress. This suggests that majority of students' parents attend school meeting only once per year as meetings are meant to increase the accountability of both parents and teachers for the children's education, so they might motivate the parents to make additional effort, regardless of whether they attended more or less. The data portray further that parents attend only annual general meetings at school as agreed by $86 \%$ of students. This suggests that parents are only attending school meetings once. Parents attending school meetings concerning their children brings awareness of the education progress of their children. There are many potential benefits of parent attending school meetings in schools. An increased parental involvement in school could improve schools' services, as well as potentially improving their accountability and transparency. These findings in comparison to with Islam, (2020) who reported that the parents who attended the most meetings could differ from the others in a number of dimensions, both observable and unobservable but it is difficult to determine the incremental benefits of attending additional meetings as parents who missed meetings might still obtain the information through later informal interactions with teachers or from other parents who attended the meetings. During an interview with parents that was conducted to investigate how frequently parents are attending school meeting and how they receive invitation from the school. One of the parents said that;

I always attend school meetings once per year and normally it happened at the end of the year. The reasons why attend school meeting at end of the year was due to get the information of my children for the whole year.(25th May 2021)

Another parent said that;

I would like to attend school meetings to understand my children education progress but I didn't get a chance to attend school meeting because the school is far away from home, then I used to send my young brother to attend school meeting for his uncle.(24th May 2021)

The results suggest that parents are more likely to attend meetings with teachers when their children are reaching the end of year and face the terminal examinations. The interactions between parents and teachers are shown to improve parental awareness about education of their children. The parents who decided to come to the meetings are likely to have different characteristics to those who did not. During an interview with District Education Officer about parents attending school meetings, the DEO has the following to say: 
Most of parents are not interested to attend school meetings. There is a need for heads of schools to conduct more than two school meetings. Conducting more than two schools meeting with parents is more important for students-to-students education while their parents got the chances to know their student's education progress.(28 ${ }^{\text {th }}$ May 2021)

This means that the benefits of school administration of conducting an extra meeting with parents might improve parents' awareness of their students' education progress. As parents learn more about their children level and progress by attending a few meetings, or perhaps even only one, the benefit of having more meetings is likely to diminish. On the other hand, attending more meetings might lead parents to feel more confident asking questions or interacting with teachers. Hence, more meetings could enhance the likelihood of effective interactions and engagements with teachers. This will help parents/guardians to make close follow ups on children school exercise books every day after school hours.

The greater majority (92\%) of students disagreed that parents attend school events such as science fair, plays and academic competitions. It is evident that greater majority of parents do not attend school events such as science fair, plays and academic competitions, signifying low awareness of contribution of school events towards children education. Furthermore, $85 \%$ of students disagreed that parents regularly attend school meetings while $10 \%$ students agreed. This means that few parents regularly attend school meetings. It is the researcher's belief that attending school meeting regularly and schools' events is important for parents and teachers to discuss the children's behaviour or academic progress. This is supported by Borgonovi \& Montt (2012) who pointed out that one way to improve poor academic results is for parents and teachers to discuss the children's behaviour or progress. That is why the researcher has been interested to see that all parents of registered students in public secondary schools are involved in various school matters including the academic activities of their children.

The same question on the extent to which parents attend school meetings enhances their children education was directed to the teachers in order to triangulate the data from the students. The result depicts that $75 \%$ of teachers disagreed that parents meet face to face with head of school to discuss about students matters while $18.3 \%$ teachers agreed. This implies that few parents meet face to face with heads of schools to discuss about students matters. This was supported by $54 \%$ of students who indicated that parents do not meet face to face with heads of schools to discuss about students matters as only few parents do meet face to face with heads of schools to discuss about students matters. About $51.6 \%$ of teachers disagreed that parents meet face to face with class teachers to discuss about their children's academic progress while $40 \%$ teachers agreed. This indicates that at least more than a quarter of parents meet face to face with class teachers to discuss about their children academic progress. This also was reported by $30 \%$ of students in table 4.5 who declared that parents meet face to face with class teachers to discuss about their children academic progress.

Parents participate in school fund raising process to enhance their children education was disagreed by $68.3 \%$ of teachers while $28.4 \%$ teachers agreed. This suggests that less than one third of parents participate on school fundraising programmes. This also reported by $16 \%$ of students which indicate that few parents do participate on school fundraising programmes. Also; the result reveals that the most parents have frequent communication with a school so as to know their children's education progress was disagreed by $56.7 \%$ of teachers while $41.7 \%$ agreed. This means that slightly less than half parents of registered students have frequent communication with a school so as to know their children's education progress. For teachers, being able to communicate with parents helps them better understand a child's strengths and their own individual personality and learning style. It's the student who benefits the most from communication between home and school, resulting in numerous positive advantages such as improved academic achievement.

Moreover; two thirds (66.6\%) of teachers disagreed that parents agreed to provide all necessary school requirements for their children to enable them study well during meeting while $30 \%$ of teachers agreed that parents agreed to provide all necessary school requirements for their children to enable them study well during meeting. This suggests that few parents agreed to provide all necessary school requirements for their children to enable them study well during meeting as most of the parents does not provide necessary schools requirement to their children.

The finding portrays further that parents attending school after being called several times by school administration as agreed by $65 \%$ of teachers while $31.6 \%$ teachers disagreed. On the other hand, slightly more than half $(53.4 \%)$ of teachers agreed that parents attend school meeting only once per year to make follow ups their children education while $40 \%$ teachers disagreed that parents attend school meetings only once per year to make follow ups their children education. This suggests that parents' attendance in school meetings is irregular or inconsistent because they are only invited at school when there is problem with their children. This was also supported by more than three quarters of students that parents attending school only after being called several times by school administration. These findings concur with Musa, (2017) who established that collaboration between the schools and parents is unsatisfactory, as both blame each other - parents blame the school for not involving them, while the schools blame parents for moving far away from the school, and for not attending meetings to which they are invited. During an interview with the heads of schools about how parents attend school meeting when they are invited at school. One of the heads of schools said that;

We have more than six hundred students in our school, but when we invite parents to attend meetings at the beginning of the year and at the end of the year, we expect to have parents more than six hundred. Unfortunately, in my headship experience I have never conducted school meetings with more than fifty percent of parents. Most of parents they don't see the importance of attending school meetings which is very concern to their children education.(26 $6^{\text {th }}$ May 2021)

Another head of school said that:

Most of parents attend school meetings because there is a problem with their children or it happens the parents are passing near the school then they show up at school about the education development of their children.(27th May 2021) 
This means that parents are only invited at school when there is problem with their children. In comparison to Jigyelet al, (2019) who reported that most parents did not see the reason for attending school meetings because at such meetings, they were hardly given the opportunity to express their views on pertinent matters.

The result indicated that $65 \%$ of teachers disagreed that parents attend school events such as science fair, plays and academic competitions while 30\% teachers agreed. This means that slightly less than one third parents attend schools' events. On the other hand, $63.3 \%$ of teachers disagreed that parents regularly attend school meetings. This means that few parents regularly attend school meetings. Also, parents agreed during school meetings to volunteer to provide guidance and counselling to their children were disagreed by $58.3 \%$ of teachers while $31.7 \%$ teachers agreed. Regardless it has been found that parents do not volunteer in various programs at school, they fail also to participate in guidance and counselling. It is the researcher's belief that guidance and counselling is important in learning process as it promotes good behaviour that leads to better academic performance. According to Mottan \& Shanmugam, (2018) who declared that school-based involvement occurs when parents actually make contact with the school and include participating in general school meetings, communicating with teachers and administrators, attending school events, and volunteering at the school.

\section{Conclusions}

Parental contribution is positively related to their children education through assisting their children homework, organizing and monitoring their children's time, attending parent teacher meetings and actively supporting school activities, volunteering in building classrooms, fieldtrips, or special events, talking with their child about school on a daily basis, encouraging their children for success and supporting them to address poor academic performances and difficulties encountered.

Based on the finding parents' attending school meetings enhance their children education. It was concluded that parents with their children at schools has to attend school meeting to know the educational performance of the children and to engage themselves to determine their level of understanding. Parent engagement happens when teachers involve parents in school meetings or events, and parents volunteer their support at home and at school. Parents has to be invited at school when there is problem with their children and sometime to create time even for once per month to attend school and meet with teachers.

\section{Recommendations}

The study recommends that government under the Ministry of Education Science and Technology (MOEST) should make sure that the parents are involved effectively to their children education by assisting their children with homework and heads of schools should encourage parent to attend school meeting to be aware with their children education. Heads of schools should encourage teachers to provide more homework assignment to the students to encourage relationship between parents and their children at home. Teachers should cooperate with head of schools and parents to enhance students' education. Students should follow what they have to be instructed by their parents and teachers.

\section{References}

i. Abbasian, R., Hadian, B., \&Vaez-Dalili, M. (2020). Examination of the Role of Family Socio-Economic Status and Parental Education in Predicting English as a Foreign Language Learners' Receptive Skills Performance. Cogent Education, 7(1).

ii. Abuya, B., Ngware, M., Hungi, N., Mutisya, M., Nyariro, M., Mahuro, G., \&Oketch, M. (2014). Community participation and after-school support to improve learning outcomes and transition to secondary school among disadvantaged girls. Retrieved from https://aphrc.org/wp-content/uploads/2021/05/ImprovingLearning-OutcomesMidterm-Report-2014.pdf

iii. Achieng, M. S. B. \&Njui, H. (2020). Parental Participation in Free Day Secondary Education and Student Retention: A Case of Migori County, Kenya. IJRDO-Journal of Educational Research, 5(7), 78-89.

iv. Amuda, B. G., \& Ali, D. G. (2016). Parents' Level of Education as Predictors of Academic Performance of Nce Students of Colleges of Education in the North- Eastern States of Nigeria. IOSR Journal of Humanities and Social Science (IOSR-JHSS), 21(2), 7.

v. Baeck, U. D. K. (2010). Parental involvement practices in formalized home-schools cooperation. Scandinavian Journal of Educational Research, 54(6), 549-563.

vi. Bill, A. A. (2016). Child rights governance. 2015-2016.

vii. Borgonovi, F. \&Montt, G. (2012). Parental Involvement in Selected PISA Countries and Economies. OECD Education Working Papers, No. 73. New Zealand. OECD Publishing Company.

viii. Conrad, C. F., \& Serlin, R. C. (2006). The SAGE Handbook for Research in Education. Thousand Oaks, CA : Sage.

ix. Dookie, S. S. (2013). An Evaluation of the Levels of Parental Involvement in Activities that Support Students Learning and how it Impacts on Students Performance. Masters Thesis: Youth Guidance, University of West Indes, pp: 10-80.

x. Epstein, J. L. (1987). Toward a theory of family-school connections: Teacher practices and parent involvement. In K. Hurrelmann, F. Kaufmann, \& F. Lose1 (Eds.), Social intervention: Potential and constraints (pp. 121-136). New York: DeGruyter.

xi. Glynn, T. (2016). Remedial Reading at Home: Helping You to Help Your Child. Set Research Information for Teachers, Number Two, Bonus Item. https://eric.ed.gov/?id=ED184081 
xii. Gonida, E. N., \& Cortina, K. S. (2014). Parental involvement in homework: Relations with parent and student achievement-related motivational beliefs and achievement. British Journal of Educational Psychology, 84(3), 376-396.

xiii. Islam, A. (2020). Parent-Teacher Meetings and Student Outcomes: Evidence from Field Experiments in Remote Communities. International Journal of Education and Literacy Studies, 1(1), 56.

xiv. Jigyel, K., Miller, J. A., Mavropoulou, S., \& Berman, J. (2019). Parental Involvement in Supporting Their Children with Special Educational Needs at School and Home in Bhutan. Australasian Journal of Special and Inclusive Education, 43(1), 54-68.

xv. Joseph, C. (2014). Factors hindering Parents Participation in School Activities in Tanzania: A Case of Arusha District. Masters Dissertation: Educational Planning and Policy Studies, Open University of Tanzania, pp: 61-80.

xvi. Kapinga, O. S. (2014). The Impact of Parental Socioeconomic Status on Students' Academic Achievement in Secondary Schools in Tanzania. International Journal of Education, 6(4), 120-132.

xvii. Kerlinger, F. N., \& Lee, H. B. (2000). Foundations of behavioral research (4th ed.). Holt, NY: Harcourt College Publishers.

xviii. Kibaara, T. M. \&Ndiragu, L. M. (2014). Parental involvement in their children's academic achievement in public secondary schools: A case of Kien-West sub-county, Nyeri County-Kenya. Nairobi: Kenya Methodist University.

xix. Kilgo, C. A., Phillips, C. W., Martin, G. L., Campbell, E., Pascarella, E. T., \&Arminio, J. (2018). Getting Critical about Critical Thinking: The Role of Parental Education on First-Generation Students' Cognitive Gains in College. Journal of College Student Development, 59(6), 756-761.

xx. Li, Z., \&Qiu, Z. (2018). How does family background affect children's educational achievement? Evidence from Contemporary China. The Journal of Chinese Sociology, 5(1), 13.

xxi. Mahuro, G. M., \&Hungi, N. (2016). Parental participation improves student academic achievement: A case of Iganga and Mayuge districts in Uganda. Cogent Education, 3(1), 1-12.

xxii. Masabo, L. P, Muchopa, E. D. \&Kuoth, B. G. (2017). Parental Involvement in School Activities in Kibondo District, Tanzania: Challenges and Remedies. International Journal of Education and Research, 5(10).

xxiii. Mauka, A. (2015). Parental Involvement and Its Effects on Students' Academic Performance in Public Secondary Schools in Korogwe District, Tanzania. Dissertation: Open University of Tanzania.

xxiv. Maxwell, C., \& Yemini, M. (2019). Modalities of Cosmopolitanism and Mobility: Parental Education Strategies of Global, Immigrant and Local Middle-Class Israelis. Discourse: Studies in the Cultural Politics of Education, 40(5), 616-632.

xxv. McLean, K., Edwards, S., Evangelou, M., Skouteris, H., Harrison, L. J., Hemphill, S. A., Sullivan, P., \& Lambert, P. (2017). Playgroups as Sites for Parental Education. Journal of Early Childhood Research, 15(3), 227-237.

xxvi. Mottan, K., \&Shanmugam, D. (2018). Role of Parents in Remedial Pupil's Academic Achievement. International Journal of Academic Research in Progressive Education and Development, 7(4), 166-178.

xxvii. Mukethe, K. S. (2015). Influence of Stakeholder Involvement in Curriculum Implementation on Pupil's Performance in Kenya Certificate of Primary Education in Katiani-Sub Country, Kenya. Ma (Ed) Thesis: Educational Administration, pp:1-8.

xxviii. Ntekane, A. (2018). Parental involvement in education. https://doi.org/10.13140/RG.2.2.36330.21440

xxix. Nzilano, J. L., \&Mtoro, S. M. (2017). The Influence of Parents on Students' Academic Performance in Tanzania: The case of Ilala Public Primary Schools. Journal of Issues and Practice in Education, 9(1), 16.

xxx. Paul, M., \&Ngirande, H. (2014). The Impact of Parental Involvement on Student Performance: A Case Study of a South African Secondary School. Mediterranean Journal of Social Sciences, 5.

xxxi. Porumbu, D., \&Necşoi, D. V. (2013). Relationship between Parental Involvement/Attitude and Children's School Achievements. Procedia - Social and Behavioral Sciences, 76, 706-710.

xxxii. Powell, D. R., Son, S. H., File, N., \& San Juan, R. R. (2010). Parent-school relationships and children's academic and social outcomes in public school pre-kindergarten. Journal of School Psychology, 48(4), 269-292.

xxxiii. Rafiq, H. M., Fatima, T., Sohail, M. M., Saleem, M., \& Khan, M. A. (2013). Parental Involvement and Academic Achievement; A Study on Secondary School Students of Lahore, Pakistan . International Journal of Humanities and Social Science, Vol. 3, No. 8, 209-223.

xxxiv. Shute, V. J., Hansen, E. G., Underwood, J. S., \&Razzouk, R. (2017). A Review of the Relationship between Parental Involvement and Secondary School Students' Academic Achievement. Education Research International, 12(4), 19.

xxxv. Spies, J., \&Heystek, J. (2015). Principals' educational practices in the field of rural villages. TydskrifVirGeesteswetenskappe, 55(3), 437-451.

xxxvi. URT. (1978). The National Education Act, 1978. Dar es Salaam.

xxxvii. URT. (2015). Warakawa Elimu Namba 6 waMwaka 2015 Kuhusu Utekelezajiwa Elimu Msingibila Malipo. Dar es Salaam: WizarayaElimu, SayansinaTeknolojia, 10/12/2015.

xxxviii. URT. (2016). WarakawaElimuNamba 3 waMwaka 2016 KuhusuUtekelezajiwaElimuMsingibilaMalipo. Dar es Salaam: WizarayaElimu, SayansinaTeknolojia, 25/5/2016.

xxxix. Uwezo. (2013). Are our children learning? Annual learning assessment reports 2010-2013. Dar es salaam: Uwezo Tanzania.

xl. Wilson, S. (2013). Determinants of Poor Academic Performance in Community Secondary Schools in Tanzania: A Case Study of Kinondoni Municipality. Published Dissertation: Open University of Tanzania. 